\title{
RFD
}

\section{A CONSTITUCIONALIDADE DO DIREITO AO ABORTO VOLUNTÁRIO NO}

\author{
SISTEMA NORTE-AMERICANO
}

\author{
THE CONSTITUTIONALITY OF THE RIGHT TO VOLUNTARY ABORTION \\ IN THE UNITED ST ATES SYSTEM
}

Teresinha Inês Teles Pires ${ }^{1}$

Resumo: Será empreendido um estudo sobre a operacionalidade do sistema norte-americano no que concerne à proteção constitucional do direito ao aborto. Como se verá, esse direito foi reconhecido pela Suprema Corte do país com fundamento no direito à privacidade enquanto uma derivação da cláusula do devido processo legal em seu caráter substantivo. $\mathrm{O}$ aperfeiçoamento dos padrões de análise utilizados pelos juízes no dimensionamento da esfera da privacidade individual, trouxe para a prática jurídica um modelo sólido e coerente de concretização das cláusulas da liberdade e da igualdade, no contexto da autonomia procriativa. Tornou-se possível, assim, a incorporação de direitos fundamentais não expressos na Constituição, dentre eles o direito à contracepção e o direito ao aborto. Além disso, pretende-se mostrar que o tema em questão envolve a necessidade de se definir limites para a tutela da vida pré-natal a partir do significado constitucional do direito à vida, o que recebeu rigorosa atenção no julgamento dos casos a serem apresentados e discutidos neste ensaio.

Palavras-chave: aborto, contracepção, liberdade, igualdade, vida potencial.

Abstract: A study on the operation of the US system regarding the constitutional protection of the right to abortion will be undertaken. As will be seen, this right was recognized by the Supreme Court of the country on the basis of right to privacy as a derivation of the due process clause in its substantive character. The improvement of standards of analysis used by the judges in the design of individual privacy sphere, brought to legal practice a solid and coherent model of implementation of the provisions of liberty and equality in the context of procreative autonomy. It has become possible, thus, the incorporation of fundamental rights not expressed in the Constitution, including the right to contraception and abortion rights. In addition, we intend to show that the issue at hand involves the need to set limits for the

\footnotetext{
${ }^{1}$ Doutora em Direito pelo Centro Universitário de Brasília. Estudos de doutoramento na American University Washington College of Law. Mestre em Filosofia pela Universidade Federal do Rio Grande do Sul. Especialista em Direito Civil pela Universidade Federal de Goiás. Promotora de Justiça do Ministério Público do Distrito Federal e Territórios.
} 
protection of prenatal life from the constitutional meaning of the right to life, which has received close attention in the trial of cases to be presented and discussed in this assay.

Keywords: abortion, contraception, liberty, equality, potential life.

INTRODUÇÃO

Pretende-se expor e analisar o percurso através do qual o direito ao aborto foi reconhecido e implementado nos Estados Unidos da América, em sede de judicial review, por meio da integração do significado de diversas cláusulas constitucionais de direitos fundamentais. Como se verá, a construção de um esquema amplo de proteção ao planejamento reprodutivo foi iniciada com a legalização do direito à contracepção. Partiu-se da definição da privacidade enquanto uma categoria de direito fundamental não expressamente prevista na Carta de Direitos (Bill of Rights). Introduziu-se, ainda, o envolvimento da cláusula da igual consideração perante a lei no momento em que se colocou a necessidade da garantia do direito à contracepção não somente às pessoas casadas, mas também às pessoas solteiras, fora do contexto das relações conjugais. A extensão posterior da proteção da privacidade ao tema do aborto, efetivada na decisão Roe $v$. Wade (ESTADOS UNIDOS, Suprema Corte, 1973), resultou na reelaboração da doutrina do devido processo legal, no sentido de que se lhe fosse conferido um estatuto substantivo, e não meramente procedimental.

O entrelaçamento entre os princípios do devido processo legal e da igual proteção perante a lei deu causa a complexas divergências no tocante à precedência de um ou de outro no julgamento dos casos nos quais se discutiu a configuração do conceito constitucional de privacidade. O resultado mais importante da investigação foi o reconhecimento de que o direito à privacidade tem plena aplicabilidade ao âmbito do controle da reprodução, o que permitiu estabelecer critérios sólidos para a apreciação da validade das leis que regulavam, de forma restritiva, o direito à contracepção.

1 PRÉVIA DA SUPREMA CORTE ACERCA DO DIREITO DE PRIVACIDADE A DISCUSSÃO 
1.2 Contracepção como liberdade básica derivada do direito de privacidade e da cláusula đo devido processo legal

Antes de se adentrar na abordagem dos casos diretamente relacionados à contracepção, far-se-á menção ao conteúdo de algumas decisões precedentes nas quais o direito de privacidade foi, inicialmente, introduzido pela atividade interpretativa na esfera da proteção das relações familiares e da autonomia procriativa como um todo. Esclareça-se que o direito à privacidade não está previsto na Constituição bem como em nenhuma das emendas constitucionais (Bill of Rights), mas acabou sendo escolhido, no ano de 1973 (Roe $v$. Wade), como fundamento central para a admissibilidade do aborto, a partir do entendimento anteriormente adotado pela Suprema Corte na regulamentação do acesso à contracepção.

A primeira decisão importante, em nível federal, no tocante à intimidade familiar não teve ainda relação com o tema da contracepção, e sim com o direito dos pais de conduzirem a educação dos filhos de acordo com suas preferências. Trata-se do caso Meyer v. Nebraska, julgado pela instância constitucional no ano de 1923. Nesta decisão, uma lei do estado de Nebraska, que proibia o ensino aos alunos de qualquer língua estrangeira nas escolas, públicas ou particulares, até a conclusão do oitavo ano, foi declarado arbitrário e inconstitucional (ESTADOS UNIDOS, Suprema Corte, 1923). ${ }^{2}$ A opinião da Corte, no sentido de que o banimento em questão representava explícita violação à liberdade de decisão individual quanto a melhor forma de educar os filhos, nos termos da Décima Quarta Emenda, ${ }^{3}$ alavancou o aperfeiçoamento de uma definição jurisprudencial do direito de privacidade. A vinculação da categoria da privacidade à proteção assegurada pela cláusula do devido processo e à obrigatoriedade de os estados demonstrarem convincentemente a existência de um interesse público que justifique restringir o exercício de qualquer direito fundamental, tornou-se pressuposto essencial da posterior legalização do aborto no país.

\footnotetext{
${ }^{2}$ O propósito da lei invalidada (Act Neb. April 9, 1919), evidentemente, era fazer com que o inglês fosse adotado como língua materna por todas as crianças educadas no estado, inclusive os filhos de famílias imigrantes.

${ }^{3}$ De acordo com a parte final do texto da emenda citada, os estados não podem: "deprive any person of life, liberty, or property, without due process of law; nor deny to any person within its jurisdiction the equal protection of the laws" (Conforme ESTADOS UNIDOS. The Constitution of the United States of America at the National Archives). Tradução livre: "privar qualquer pessoa da vida, liberdade, ou propriedade, sem o devido processo legal; nem negar a qualquer pessoa, dentro de sua jurisdição, a igual proteção das leis".
} 


\section{RFD}

No caso Pierce v. Society of Sisters of the Holy Names of Jesus and Mary (ESTADOS UNIDOS, Suprema Corte, 1925), os juízes invalidaram uma lei adotada pelo estado de Oregon, que obrigava os pais a matricularem seus filhos, na idade de 8 a 16 anos, exclusivamente em escolas públicas, entendendo que a medida violava o direito de escolha dos pais em relação ao local apropriado para a formação educacional dos filhos e, também, o direito das corporações privadas de empreenderem autonomamente seus próprios negócios. O fundamento da decisão foi mais uma vez a Décima Quarta Emenda, que protege a autonomia familiar e o direito de propriedade no tocante ao exercício de atividade lucrativa lícita.

A evolução do debate judicial acerca da privacidade prosseguiu no julgamento do caso Olmstead v. U.S. (ESTADOS UNIDOS, Suprema Corte, 1928), em que se apreciou pedido de declaração da inconstitucionalidade de interceptação telefônica realizada, sem autorização judicial prévia, com o intuito de instruir ação criminal pela prática de crime federal. A análise, dessa vez, centralizou-se na proteção constitucional da casa, intimidade, e documentos pessoais, contra as apreensões arbitrárias do poder público, sem o devido mandado de busca (Quarta Emenda), e nas garantias contra condenações, prisões e produção de provas em desacordo ao devido processo criminal (Quinta Emenda). A Suprema Corte, entretanto, sustentou a validade da medida, concluindo que o bem por ela atingido não se enquadra no conceito de "pessoa", "casa” ou "papéis", no sentido das Emendas invocadas, com o que as evidências apresentadas no respectivo julgamento não foram consideradas abusivas e contrárias ao texto constitucional (ESTADOS UNIDOS, 1928, p. 465-6.).

Essa decisão atribuiu conteúdo mais estreito ao direito de privacidade. Como afirmado pelo juiz Brandeis, dissidente no caso, a Corte fechou os olhos para o crescimento dos meios sutis e silenciosos postos à disposição do governo para ter acesso à intimidade das pessoas, o que caracteriza forma de controle até mais efetiva do que as formas tradicionais de invasão física da residência. A interceptação telefônica expõe a integralidade das conversas entabuladas no aparelho cooptado, incluindo os assuntos confidenciais, ao conhecimento dos oficiais do governo, transformando-se em verdadeiro instrumento de opressão e exercício autocrático do poder (ESTADOS UNIDOS, Suprema Corte, 1928, p. 473-6). Curiosa a atualidade desse comentário, quando se lembra a decisão proferida pelo juiz federal Richard Leon, da Corte Distrital do Distrito de Columbia, em 16/12/13, declarando inconstitucional o programa do governo federal de combate ao terrorismo, em relação à coleta de dados 


\section{RFD}

armazenados em telefones celulares de todos os cidadãos norte-americanos. Firmou-se qüe o interesse do governo na preservação da segurança nacional não justifica tamanho grau de invasão da privacidade individual (ESTADOS UNIDOS, Corte Distrital, DC, 2013).

Em um precedente de maior densidade jurídica, a Suprema Corte anulou uma lei do estado de Oklahoma, que determinava a obrigatória esterilização dos condenados duas ou mais vezes por crimes contra o direito de propriedade praticados mediante uso de violência (ESTADOS UNIDOS, 1942). Aqui a autonomia procriativa foi inserida no contexto da apreciação constitucional do direito de privacidade. A opinião do juiz Douglas enfatizou a cláusula da igual proteção (Décima Quarta Emenda), aduzindo que a classificação operada pela lei, no caso, é discriminatória, no tocante a determinados indivíduos ou grupos, sem comprovação alguma de que os crimes elegidos pelo decreto de esterilização importam em maior probabilidade de transmissão hereditária que os demais crimes. Em matéria de direitos fundamentais, as classificações legais sujeitam-se a um grau maior de controle judicial e a uma exigência máxima de que os estados demonstrem seu interesse e a necessidade da imposição de restrições normativas à conduta individual, o que recebe o nome, nos países de common law, de "padrão do escrutínio rígido" (ESTADOS UNIDOS, Suprema Corte, 1942, p. 541).

Saliente-se que foram estabelecidos no sistema norte-americano três padrões básicos para a análise da constitucionalidade das leis: i) o escrutínio mais rígido (strict scrutiny), aplicável aos direitos fundamentais assegurados à luz da cláusula do devido processo (due process clause) e da cláusula da igual proteção (equal protection clause) no tocante às classificações suspeitas, tais como raça ou nacionalidade. Esse padrão exige que o governo demonstre um interesse imperativo, da maior relevância, na restrição imposta pelas leis; ii) o escrutínio intermediário (intermediate scrutiny), aplicável à luz da equal protection clause em relação às classificações "quase suspeitas”, tais como diferenças de tratamento com base em gênero ou idade, que exige do governo a comprovação de um interesse substancial, um objetivo importante, que justifique a restrição a direito individual; e iii) o escrutínio de base racional (rational-basis scrutiny), aplicável aos direitos protegidos pela due process clause que não tenham o estatuto de direitos fundamentais e àqueles protegidos pela equal protection clause quanto às classificações não suspeitas, em tese, como, por exemplo, em matéria de "regulação econômica", em relação às quais o governo precisa apenas evidenciar uma base racional que vincule a restrição da lei a um interesse público legítimo. Em linguagem sintética, 


\section{RFD}

se o preceito prioritário envolvido no caso em julgamento é a equal protection clause, 'as

Cortes utilizam um dos três padrões de análise dependendo da matéria objeto da classificação legal; e se o preceito prioritário é o da due process clause, são utilizados o primeiro ou o último padrão, ou seja, ou o caso deve ser julgado à luz do strict scrutiny ou do rational-basis scrutiny, não havendo lugar para o intermediate scrutiny. ${ }^{4}$

Em muitos casos, é até mesmo difícil identificar, com precisão, nos argumentos dos juízes, qual o padrão utilizado. Não obstante, no caso Skinner v. State of Oklahoma (ESTADOS UNIDOS, Suprema Corte, 1942), por exemplo, os juízes utilizaram, explicitamente, a doutrina do strict scrutiny, embora não tenham amadurecido, suficientemente, suas premissas analíticas, referindo-se ao conceito em sua forma genérica. Não se avançou, dentre outros aspectos, a discussão quanto à aplicação do escrutínio mais rígido aos direitos não enumerados, previstos na Nona Emenda. ${ }^{5}$

Outro elemento significativo na argumentação desenvolvida no caso Skinner v. State of Oklahoma foi a divergência manifestada entre os magistrados, no que pese a decisão ter sido unânime quanto ao mérito, na escolha da cláusula constitucional mais adequada para a afirmação do direito em apreciação. O juiz Douglas, como já mencionado, fundamentou seu voto na cláusula da igual proteção. O juiz Stone, ao contrário, fundamentou seu voto na cláusula do devido processo, entendendo que não se pode presumir a natureza discriminatória da classificação da lei. Isso porque os estados, em seu interesse de reduzir a criminalidade nas futuras gerações, poderiam considerar, pelas circunstâncias psíquicas de cada pessoa, que determinadas condutas criminosas, quando reiteradas, denotam maior tendência a serem transmitidas hereditariamente. Segundo Stone, o que está em questão na proibição da esterilização compulsória é se tão excessivo nível de intrusão na liberdade individual de um grupo específico, sem um procedimento que possibilite ao condenado apresentar as razões pelas quais acredita não se enquadrar na presunção legal, constitui uma ação legítima dos estados. Por fim, o Juiz Jackson defendeu a aplicação das duas cláusulas, ponderando que

\footnotetext{
${ }^{4}$ De acordo com o quadro explicativo formulado por FINE, Toni. Introdução ao sistema jurídico AngloAmericano. São Paulo: WMF Martins FONTES, 2011, p. 30. No âmbito das decisões da Suprema Corte, uma boa explicação desses padrões da judicial review pode ser lida na opinião do juiz Alito no caso U.S. v. Windsor (ESTADOS UNIDOS, 2013).

${ }^{5}$ Voltar-se-á a problematizar, ao longo da análise de outros casos, a importância do padrão do strict scrutiny na regulamentação de matérias como contracepção e aborto. Conforme se verá, o rompimento com esse padrão de controle da ação governamental, a partir das decisões posteriores à era Roe $v$. Wade, acarretou a diminuição e a relativização dos direitos das mulheres ao passo em que aumentou o poder interventivo dos estados.
} 


\section{RFD}

um amplo modelo de classificação legal, protegido pela cláusula da igual proteção, se caracterizaria exatamente pela inclusão da manifestação do indivíduo como uma exigência do devido processo legal (ESTADOS UNIDOS, Suprema Corte, 1942, p. 544-6).

A centralidade de determinada provisão constitucional na garantia dos direitos reprodutivos é bastante controversa e representa o ponto mais sensível no tocante ao balizamento entre liberdades individuais e intervenção estatal. No julgamento dos casos posteriores a Skinner, referentes à contracepção e ao aborto, a questão foi sempre um dos maiores focos de divergências e estratégias argumentativas utilizadas na defesa das posições conflitantes.

No caso Griswold v Connecticut o direito de privacidade foi redimensionado para inserir-se no âmbito das relações conjugais, no que toca à liberdade de utilização de métodos contraceptivos de acordo com o planejamento familiar do casal e com a orientação do médico escolhido (ESTADOS UNIDOS, Suprema Corte, 1965). ${ }^{6}$ A decisão declarou a lei então questionada inconstitucional por invadir o direito de privacidade marital, violando, assim, a garantia do devido processo legal, na forma instituída pela Décima Quarta Emenda. O devido processo legal foi o fundamento exclusivo em Griswold, razão pela qual a Corte teve a oportunidade de ampliar seu significado na limitação do poder estatal no controle das liberdades individuais. Foi assentado que o devido processo legal abrange não apenas as garantias enumeradas, mas igualmente as que estejam implicitamente nelas incluídas.

A noção do devido processo legal substantivo recebeu, assim, significativa evolução, como uma categoria essencial para a vinculação entre os direitos protegidos pelas primeiras oito emendas e a cláusula da liberdade na forma veiculada pela Décima Quarta Emenda (due process clause). Nos precedentes já mencionados, não se estruturou claramente um modelo interpretativo que permitisse a descoberta de direitos fundamentais não expressos. Em

\footnotetext{
${ }^{6}$ Em linhas gerais, o assunto chegou à Suprema Corte através de apelo interposto por alguns médicos, os quais haviam sido condenados por terem fornecido instruções e conselhos profissionais aos seus pacientes casados no que concerne à prevenção da contracepção, em desacordo com dispositivo de uma lei promulgada pelo estado de Connecticut, proibitiva da conduta praticada pelos apelantes. Segundo a lei em espécie, o uso generalizado, por qualquer pessoa, de artigos medicinais para fins de prevenção da gravidez estaria sujeito a multa de no mínimo cinquenta dólares e a prisão por um período de sessenta dias a um ano. Nos termos dos dispositivos legais gerais do estado de Connecticut, as mesmas penalidades se aplicariam àqueles que aconselhassem ou prescrevessem a outras pessoas a realização do ato proibido. Não é tão importante, para os propósitos desse estudo, a argumentação referente à caracterização da conduta dos médicos como sendo criminosa ou não, o que a Corte considerou negativamente. Importa, antes, a forma como a elaboração de um padrão aberto para a definição do direito constitucional à privacidade foi assentado nesse julgamento, no que se concentrará a análise que se segue.
} 


\section{RFD}

Griswold, os juízes conseguiram vislumbrar que os direitos anteriormente afirmados de autonomia na educação dos filhos (Meyer e Pierce) também não estavam expressamente previstos na Constituição ou na Bill of Rights. Os juízes perceberam, assim, que esses direitos eram legítimos porque emanavam das liberdades de expressão e de pensamento, asseguradas pela Primeira Emenda. Nas palavras do juiz Douglas, "a Primeira Emenda tem uma penumbra onde a privacidade está protegida contra a intrusão governamental" (ESTADOS UNIDOS, Suprema Corte, 1965 , p. 483). ${ }^{7}$ O devido processo legal não se resume aos aspectos procedimentais da Bill of Rights, abrangendo igualmente suas imposições de caráter substantivo, que limitam o exercício do poder estatal (BARRON, 2013, p. 216). ${ }^{8}$ Não se trata, portanto, de concretizar exclusivamente as liberdades especificadas na Constituição, mas de afirmar a supremacia dos direitos fundamentais, em sentido amplo, contra qualquer tipo de arbitrariedade pública impeditiva de sua plena eficácia (WENZ, 1992, p. 24).

Nessa perspectiva, a fundamentação da decisão, em Griswold, uniu, por uma interpretação de caráter substantivo da cláusula do devido processo legal, a proteção da autonomia nas relações intrafamiliares (Pierce) e a proteção da autonomia procriativa (Skinner) (WENZ, 1992, p. 24). Contudo, a argumentação girou em torno da proteção da intimidade da vida marital, ${ }^{9}$ perdendo-se a oportunidade de promover um debate mais significativo no tocante aos direitos reprodutivos. Ainda assim, Griswold é o principal precedente da decisão Roe v. Wade, por ter avançado, de forma importante, a proibição da intervenção do Estado em determinadas matérias afetas ao pensamento independente e à conduta humana (BROWN et al, 1971, p. 900).

Nesse tempo, o debate acerca da autonomia procriativa e do controle da natalidade não se centralizava nos direitos das mulheres. É evidente que isso não retira o valor dos progressos que se seguiram à decisão do caso Griswold. No entanto, mesmo em Roe v. Wade, é bom salientar, não foi a mulher e a proeminência de suas prerrogativas na definição do projeto da maternidade o fator determinante para a legalização do aborto, mas sim a preservação da atuação dos médicos envolvidos na prática do aborto ilegal, que aumentava mais e mais desde os anos trinta, em decorrência da depressão econômica que assolou o país. A despeito de tais elementos, que estão nas entrelinhas da cultura jurisprudencial da época,

\footnotetext{
${ }^{7}$ No original: "the First Amendment has a penumbra where privacy is protected from governmental intrusion". ${ }^{8}$ Ver, também, GREENE, Jamal. The so-called right to privacy, 43 U.C. Davis Law Review 715, February 2010. Disponível em: <http://ssrn.com/abstract=1456026>. 2010, p. 720-3, Acesso em 25 nov. 2013

${ }^{9}$ Veja-se, nesse sentido, o voto do juiz Goldberg, ESTADOS UNIDOS, Suprema Corte, 1965, p. 495-7.
} 


\section{RFD}

o dimensionamento do direito à privacidade, enquanto um freio à arbitrariedade dos estadbs na regulamentação das relações familiares e das relações médico-paciente, foi o primeiro passo para envolver no esquema constitucional o reconhecimento do caráter fundamental da autonomia procriativa.

Ao julgar Griswold a Suprema Corte não vislumbrou a necessidade da abordagem do princípio da igual proteção perante a lei. No caso Skinner, como já dito, esse princípio foi objeto de análise, na tentativa de afirmar que a esterilização compulsória de um grupo de condenados por crimes específicos importava em uma classificação discriminatória. Mas a discussão do assunto diluiu-se dentro da argumentação como um todo, que terminou enfatizando mais a proteção da liberdade (due process clause). Em linhas gerais, a discriminação de gênero, em particular, não foi sequer mencionada nos precedentes à era Roe v. Wade, em matéria de contracepção. Os movimentos das mulheres que avançaram a busca dos seus direitos civis estavam no início, e não contavam com elementos conceituais suficientes para provocar uma reflexão, no que toca à afirmação dos seus direitos, a partir de uma linguagem propriamente feminista, não focada apenas na privacidade familiar. Não era ainda perceptível que ao falar-se em contracepção o sujeito diretamente envolvido na pretensão, em caráter primordial, era a mulher e não o casal, o homem ou os médicos (SIEGEL, 2010, p. 1884-5).

Nesse contexto, o direito à privacidade foi delineado, em Griswold, como um direito derivado, inicialmente, da proteção da vida íntima e da inviolabilidade da casa das pessoas (Terceira e Quarta Emendas). Firmou-se, ainda, que a privacidade estaria incluída nas garantias do processo criminal, como o direito de não testemunhar contra si mesmo (Quinta Emenda) (ESTADOS UNIDOS, Suprema Corte, 1965, p. 484). Além disso, defendeu-se o entendimento no sentido de que os direitos fundamentais protegidos pelas primeiras oito emendas foram incorporados à cláusula do devido processo legal, veiculada pela Décima Quarta Emenda, seja explicitamente, seja implicitamente. Em outras palavras, afirmou-se que aqueles direitos estão implicados no princípio da liberdade protegida pela Décima Quarta Emenda. Este argumento permitiu, inclusive, a identificação da privacidade enquanto um direito não enumerado, conforme previsão contida na Nona Emenda. A abordagem conjunta de diversas cláusulas constitucionais protetivas do direito à contracepção contribuiu para a 
afirmação, em termos gerais, de um sistema integral de garantia das liberdades individuăis

aplicável não somente à ação dos estados como também à ação do governo federal. ${ }^{10}$

\section{O argumento da incorporação possibilitou o aperfeiçoamento do estatuto substantivo}

da due process clause da Décima Quarta Emenda, que passou a representar uma base constitucional sólida para a presunção da não validade das leis violadoras dos direitos fundamentais, transferindo ao governo o ônus de demonstrar a necessidade da restrição imposta em suas políticas. Trata-se de uma concepção que foi inicialmente introduzida no caso Lochner v. New York (ESTADOS UNIDOS, Suprema Corte, 1905), ${ }^{11}$ tendo sido abandonada na década de 1930, por motivos econômicos, em que o governo foi forçado a

${ }^{10}$ De acordo com BARRON, Jerome A, et al. Constitutional law in a nutshell. Eighth edition. St. Paul: West Publishing Co, 2013, p. 211-2, a teoria da incorporação integral dos direitos fundamentais ao princípio da liberdade da Décima Quarta Emenda foi proposta pelo juiz Black no caso Adamson v. People of State of Califórnia, 332 U.S. 46 (1947), como uma metodologia para interpretar a extensão da due process clause. Segundo Black, tal compreensão confere maior objetividade e certeza de conformação à intenção original dos autores da Constituição. A outra teoria apresentada no mesmo caso, pelo juiz Frankfurter, arguiu que o comando da due process clause deve ser buscado no sentido de justiça socialmente aceito. Para Black, contudo, essa teoria apenas levaria ao resgate das superadas categorias do direito natural. Esclareça-se que existe uma discussão na doutrina norte-americana em relação à aplicabilidade das primeiras emendas constitucionais ao poder normativo dos estados federados. Como indicado na nota supra $\mathrm{n}^{\circ} 2$, apenas a Décima Quarta Emenda determina textualmente, em sua parte final, que para limitar direitos fundamentais os estados se condicionam ao imperativo da due process clause. A Primeira Emenda, por exemplo, que prescreve a liberdade religiosa, de expressão, de imprensa, e de assembleia, é dirigida ao Congresso, e não aos estados (Ibidem, p. LIX e LXIII). É inquestionável que os autores da Primeira Emenda visavam limitar apenas os atos do Governo Federal. As restrições que possam, doravante, ser impostas aos estados derivam da Décima Quarta Emenda, conforme ESTADOS UNIDOS, Suprema Corte, 1963, p. 253. Daí a importância do envolvimento das primeiras oito Emendas na liberdade veiculada pela due process clause (Décima Quarta Emenda), como postulado pelo juiz Black. Por meio de sua tese, a discricionariedade dos estados nas restrições dos direitos individuais passa a estar indubitavelmente submetida ao controle da Suprema Corte Federal. Em outra dimensão, a integração entre as primeiras oito Emendas e as cláusulas da Décima Quarta Emenda permite a aplicação ao governo federal das amplas exigências desta última em matéria de proteção genérica à liberdade e à igualdade. Vê-se que o esquema de interpretação constitucional é complexo e sofisticado. De um lado, as Emendas elaboradas pelos formuladores da Constituição direcionam-se aos atos do Congresso, mas não aos atos dos estados. De outro lado, a Décima Quarta Emenda, posteriormente acrescentada, direciona-se aos atos dos estados, mas não aos atos do governo federal. A tese da integração das categorias fundamentais firmadas em todas as Emendas soluciona o impasse, o que é coerente e fortalece o sistema de controle da jurisdição constitucional. Uma ótima abordagem explicativa sobre o assunto, cuja leitura ora se recomenda, é apresentada por STEVENS, 1992, p. 21-7. Ver, também, AMAR, Akhil Reed. The Bill of Rights Primer: a Citizen's Guidebook to the American Bill of Rights. New York: Skyhorse Publishing, 2013, p. 55-6, 64-5 e 219-24.

${ }^{11}$ Através da abordagem da autonomia individual no estabelecimento das regras dos contratos de trabalho, a Corte apresentou, nesse caso, importante análise, à luz da Décima Quarta Emenda, a respeito dos limites do poder de polícia dos estados. Conforme enfatizado pelo juiz Peckham, a atuação do governo, muitas vezes necessária, pode configurar, em determinadas circunstâncias, uma ingerência ilegítima, dispensável, e não fundamentada em razões públicas, no protegido exercício da liberdade individual. Afirmou-se, assim, a supremacia da função judicante na apreciação dos comandos normativos, em relação às matérias dispostas nas cláusulas fundamentais (Ibidem, 1905, p. 56-7). Acrescente-se, ainda, que essa direção adveio não apenas do adensamento da substantive due process clause, mas também da aplicação do padrão da "autorrestrição" (selfrestraint) ao poder de polícia do governo. Saliente-se, por fim, que a self-restraint caracteriza a doutrina da limitação dos poderes dos juízes na interpretação das leis sob o pressuposto da prevalência, na fase de sua elaboração, do processo deliberativo-democrático. 


\section{RFD}

reduzir direitos. Em Roe v. Wade a mesma concepção foi resgatada e adotada, amplamente, sob a influência das decisões Meyer v. Nebraska, Pierce v. Society of Sisters of the Holy Names of Jesus and Mary e Skinner v. Oklahoma, casos já mencionados acima (WENZ, 1992, p. 18-23).

Laurence Tribe adota, explicitamente, a doutrina da incorporação (Black) e, por conseguinte, o sentido substantivo da due process clause. Acentua que a redução dessa cláusula ao seu aspecto puramente procedimental é insustentável, não havendo nenhuma base para a limitação dos direitos de liberdade àqueles especificamente mencionados na Bill of Rights. A liberdade, em sua conotação substantiva, é a fonte de todas as outras liberdades constitucionais, inclusive dos direitos não enumerados da Nona Emenda, que, portanto, também se aplicaria aos estados. Tribe é um forte defensor da autoridade da Suprema Corte na especificação dos direitos fundamentais e dos preceitos a serem utilizados na concretização do âmbito protetivo da liberdade definida na Décima Quarta Emenda (TRIBE, 1990, p. 87-8 e 90-1). ${ }^{12}$

Voltando ao caso Griswold, saliente-se que não houve unanimidade na aceitação da tese da incorporação dos direitos expressos no conteúdo da Décima Quarta Emenda, por meio do sentido substantivo da due process clause. O Juiz Goldberg manifestou sua discordância, nesse aspecto, acentuando que a vinculação da liberdade, nos termos da Décima Quarta Emenda, ao texto da Nona Emenda (direitos não enumerados) é suficiente para se concluir que os direitos fundamentais não se resumem àqueles enunciados nas primeiras oito emendas, e para assentar, assim, a proteção da privacidade nas relações conjugais em matéria de planejamento familiar (ESTADOS UNIDOS, Suprema Corte, 1965, p. 486-7 e 491-3). O juiz Harlan acompanhou esse entendimento, afirmando que a cláusula do due process, em sua aplicação aos casos concretos, é 11 autossuficiência, não dependendo das provisões

\footnotetext{
${ }^{12}$ É oportuno salientar a concepção de DWORKIN, Ronald. Freedom's law: the moral reading of the American Constitution. Cambridge, Massachussets: Harvard University Press, 1996, p. 76-81, de que a distinção entre direitos enumerados e não enumerados não tem nenhuma utilidade na interpretação constitucional da Bill of Rigths. A proximidade entre um direito concreto, como o caso do aborto, à linguagem constitucional deve ser firmada em uma perspectiva holística, por meio de argumentos não mediatizados por categorias abstratas adicionais, focando-se tão somente nos princípios enunciados na Constituição e no requisito da coerência. No mesmo sentido, ainda segundo DWORKIN, Ronald. Unenumereted Rights: Whether and How Roe Should be Overruled, 59 University of Chicago Law Review 381, Winter 1992, p. 382, 387 e 390, o sistema de prescrições constitucionais é integrativo, porque se sustenta, com peso equivalente, tanto na liberdade genérica quanto na igual consideração perante a lei. Alguns princípios são abstratos, uns mais outros menos, enquanto outros princípios são concretos, mas, em seu conjunto, definem um projeto político, consubstanciado na idealização de uma sociedade na qual os direitos de igual liberdade e de cidadania sejam efetivamente usufruídos.
} 


\section{RFD}

especificadas na Bill of Rights, que podem, no máximo, auxiliar a investigação (ESTADOS UNIDOS, 1965, p. 500).

Os votos divergentes, apenas dois, centraram-se na consideração de que o direito de privacidade seria revestido de alto grau de obscuridade, permitindo que qualquer questão seja nele incluída, ao ponto de atribuir ao poder judiciário a prerrogativa para invalidar qualquer ato legislativo que repute não razoável ou ofensivo, de acordo com a noção particular dos juízes acerca do significado concreto da vida privada. Da mesma maneira, a cláusula do devido processo legal não teria sido concebida para dimensionar a esse grau o poder de revisão judicial (ESTADOS UNIDOS, Suprema Corte, 1965, p. 509-12). ${ }^{13}$ Segundo o Juiz Stewart, dissidente, não poderia a lei combatida pelos apelantes ser anulada por violação ao devido processo legal (Décima Quarta Emenda), uma vez que não foi negado aos apelantes a obediência ao correto procedimento no curso do julgamento criminal, inexistindo qualquer equívoco jurídico capaz de tornar a condenação passível de ser declarada inconstitucional (ESTADOS UNIDOS, Suprema Corte, 1965, p. 528). ${ }^{14}$

O argumento da 12autossuficiência do devido processo legal, em sentido substantivo, é de difícil sustentação, e enfraquece qualquer perspectiva de se responder satisfatoriamente às indagações apresentadas nos votos divergentes, anteriormente resumidas. O direito de liberdade, em sua forma genérica, não justifica, por si só, a inclusão do direito à privacidade no rol dos direitos fundamentais, aspecto em relação ao qual se pode concordar com o juiz Black. Enquanto cláusula abstrata, o devido processo legal não configura, em caráter exclusivo, um critério seguro para a construção de um padrão aceitável de análise constitucional no âmbito da prática interpretativa. Por outro lado, não se pode concordar com Black quando afirma que nenhuma das provisões constitucionais oferece guarida para a proteção da privacidade, em Griswold, e que a liberdade de expressão (Primeira Emenda) não protege a conduta dos médicos condenados pela prescrição de contraceptivos em desacordo

\footnotetext{
${ }^{13}$ No tocante ao devido processo legal, a mesma opinião foi manifestada no voto dissidente do juiz Harlan, no caso Lochner v. New York, que arguiu a impropriedade do alargamento da concepção original da Décima Quarta Emenda (ESTADOS UNIDOS, Suprema Corte, 1905, p. 73-4).

${ }^{14}$ Observa-se que a opinião de Stewart respalda a due process clause somente em seu sentido procedimental, desconsiderando os argumentos desenvolvidos pelos demais juízes no aperfeiçoamento da substantive due process clause. A crítica de Stewart é facilmente rebatida quando se pressupõe esse aperfeiçoamento, pois o devido processo legal, no caso, não deixou de ser observado em relação ao regular procedimento criminal, e sim em relação à proteção constitucional do direito de expressão (Primeira Emenda) dos condenados e em relação à proteção constitucional do direito de autodeterminação das pessoas casadas nas decisões que concernem ao planejamento reprodutivo-familiar (derivativo da Quarta emenda).
} 


\section{RFD}

com lei (ESTADOS UNIDOS, Suprema Corte, 1965, p. 508-9 e 521). Adotando a concepção de Black, mas contrapondo-se à sua opinião no caso Griswold, entende-se que a ideia da incorporação no significado substantivo da Décima Quarta Emenda dos direitos, expressamente protegidos nas oito primeiras emendas, melhor fundamenta a garantia da privacidade. Postular o envolvimento da due process clause no conteúdo das cláusulas da liberdade de expressão e de pensamento permite conferir-lhe densidade no tocante ao controle dos atos arbitrários dos estados, sujeitos, nessa matéria, ao strict scrutiny standard.

Lembre-se que o padrão do strict scrutiny é normalmente invocado na interpretação acerca dos direitos fundamentais enumerados, sendo que o grau de exigência na demonstração do interesse interventivo do governo depende, regra geral, da intensidade do ônus decorrente da restrição do direito em questão. Por outro lado, quando se trata de um direito fundamental não enumerado, como privacidade ou relações familiares, é bastante problemático ampliar os limites da atividade jurisdicional no controle das leis. Para alguns críticos, o conceito de strict scrutiny nada mais representa do que a doutrina da adjudicação judicial em linguagem alternativa, cujo sentido consiste no resgate dos pressupostos do direito natural à luz da cláusula do devido processo legal (BARRON, 2013, p. 235-7). Em contrapartida, como destacado pelo juiz Harlan, o parâmetro da self-restraint, embora seja indispensável para o exercício do poder constitucional revisional, não tem aplicação significativa na esfera das liberdades básicas. Se o tivesse, poderia ser inadequadamente invocado como um artifício para restringir o conteúdo da due process clause (ESTADOS UNIDOS, Suprema Corte, 1965, p. 501-2).

Equilibrar os padrões do strict scrutiny e da self-restraint é questão crucial na definição do papel dos poderes legislativo e judiciário na regulamentação tanto da contracepção quanto do aborto. Um posicionamento moderado que estruture o modelo do strict scrutiny sem cair nos excessos da opinião liberal extremista revela-se o mais adequado. Não é plausível, entretanto, concordar com a opinião de que a doutrina da incorporação (direitos enumerados e due process clause) possa reduzir a amplitude da liberdade prescrita na Décima Quarta Emenda. Acredita-se, ao contrário, que tal doutrina possa até estender a aplicação da due process clause aos casos concretos e delimitar corretamente os parâmetros da self-restraint. A tese da incorporação não importa no esvaziamento da Nona Emenda (direitos enumerados). Apenas indica que a direção inicial, na interpretação constitucional, consiste na ponderada extensão do âmbito de proteção dos direitos expressos, reservando-se, para 


\section{RFD}

uma segunda análise, a perquirição acerca da dicção de novos direitos fundamentais cóm base em um raciocínio derivativo.

É com essa concepção que se defende, para uma resposta eficaz aos críticos do controle jurisdicional de constitucionalidade, a conjugação entre as cláusulas abstratas e as cláusulas específicas de direitos fundamentais, de maneira a dar-lhes conteúdo e efetividade máximos. Entende-se que essa conjugação contribuiu para o estabelecimento de um padrão rígido de análise das leis restritivas em matéria de direitos reprodutivos, na fase inicial de sua abordagem, e para uma definição aceitável do conceito de privacidade. Em Griswold, verificou-se que a meta pretendida pelo estado de Connecticut não tinha consistência o bastante para legitimar, no esquema do strict scrutiny, a restrição imposta ao direito ao planejamento familiar. A rationale da lei, segundo arguição dos apelados, seria desestimular as relações extraconjugais, incentivando, assim, a estabilidade familiar, por meio da criação de empecilhos ao controle de natalidade. A proibição do uso de contraceptivos com base em tal justificativa revelou-se, perante a Corte, medida desnecessária e atentatória ao sistema de garantias fundamentais (ESTADOS UNIDOS, Suprema Corte, 1965, p. 497-8 e 505). Com efeito, se existem questões morais envolvidas, nesse caso, trata-se de um juízo atinente à esfera da moralidade privada. $\mathrm{O}$ uso individual de contraceptivos não pode ser considerado uma conduta que tende a comprometer a moralidade pública ao ponto de desestabilizar a pacificação social. Nesse particular, é bom frisar, por fim, que a interação argumentativa entre a due process clause e as liberdades de expressão e de pensamento, sustentada em Griswold, favorece a sobreposição da autonomia moral na esfera procriativa, salvo na hipótese de existência de um interesse irresistível do Estado.

1.2 Introdução da abordagem da cláusula da igual proteção em matéria de contracepção e controle de natalidade

Não levou muito tempo para que o direito de privacidade voltasse a ser posto na agenda do poder judiciário, dessa vez com novos elementos de indagação acerca do alcance das cláusulas constitucionais protetivas da liberdade individual no contexto reprodutivo. No caso Einsenstadt v. Baird, uma lei estadual foi declarada inconstitucional pela Suprema Corte 


\section{RFD}

por excluir expressamente o acesso das pessoas solteiras à utilização de métodbs contraceptivos (ESTADOS UNIDOS, Suprema Corte, 1972). ${ }^{15}$

A intenção do Estado, explicitada na lei, era preservar a moral convencional através da regulamentação das relações sexuais das pessoas solteiras, sob a crença de que isso diminuiria a atividade sexual pré-matrimônio e as possibilidades de conluio entre casados e solteiros (ESTADOS UNIDOS, Suprema Corte, 1972, p. 442 e 449). Como não poderia ter sido diferente, a Suprema Corte acentuou, seguindo seu precedente (Griswold), a não aceitabilidade do argumento do Estado no sentido de que proibindo o acesso aos métodos medicamentosos de contracepção se estaria protegendo a saúde das pessoas e, ao mesmo tempo, conservando o modelo familiar tradicional de relacionamento afetivo. Não há fundamento, sob o prisma do princípio da igual proteção perante a lei, para distinguir os direitos de privacidade a partir do estado civil das pessoas. Do ponto de vista da proteção à saúde, o Estado tampouco conseguiu demonstrar seu interesse em banir a distribuição de contraceptivos às pessoas solteiras, assim como não conseguiu demonstrar que isso pudesse representar uma forma razoável de prevenção médica da gestação. Se as pessoas casadas podem livremente optar pelo uso de medicamentos contraceptivos, mesmo ponderando os riscos potenciais daí decorrentes para a sua saúde, é forçoso concluir que a mesma autonomia deve ser conferida aos não casados. No tocante ao interesse público no desestímulo ao sexo antes do casamento ou às relações sexuais extramaritais entre pessoas casadas e solteiras, não há como afirmar a legitimidade de uma intenção como essa em detrimento da liberdade de escolha no que se refere à prevenção procriativa.

\footnotetext{
${ }^{15}$ A mencionada lei foi promulgada pelo estado de Massachusetts com o intuito de regulamentar a distribuição dos instrumentos contraceptivos. Em face da decisão Griswold v. Connecticut, os legisladores entenderam legítima a proibição da disponibilidade de tais instrumentos às pessoas solteiras para fins de prevenção da gravidez, permitindo-se-lhes o acesso unicamente para o controle de doenças. Desse modo, perante a lei, a distribuição, por parte de qualquer pessoa, de métodos contraceptivos visando evitar a procriação, somente estaria autorizada às pessoas casadas. $\mathrm{O}$ autor do apelo dirigido à Suprema Corte, neste caso, foi condenado por ter exibido, em uma palestra, mercadorias anticonceptivas e por ter entregado a uma mulher jovem um pacote contendo esse tipo de artigo. A Corte estadual já havia afastado, por unanimidade, a condenação dos apelantes pelo ato de exibirem os instrumentos na palestra, com fundamento no seu direito de expressão (Primeira Emenda), mas restou mantida a condenação pela distribuição do produto à mulher interessada, considerando os termos da lei regulamentadora do assunto. A diferença em relação à lei de Connecticut, que deu causa à ação julgada no caso Griswold, reside no fato de que neste a lei invalidada proibiu o uso de instrumentos contraceptivos enquanto que no caso Einsenstadt a lei proibiu sua distribuição. Isso não modifica os aspectos debatidos para a concretização do direito à privacidade. Ao contrário, observa-se que a reflexão seguiu, de um caso para o outro, uma linha evolutiva em direção ao aperfeiçoamento do direito de decisão quanto a ter ou não ter filhos e quanto ao momento de fazê-lo.
} 


\section{RFD}

Como já se sabe, quando se opera uma distinção entre grupos específicos de pessoås, em matéria de direitos fundamentais, aplica-se, na maioria dos assuntos, o padrão do strict scrutiny na avaliação da pertinência das razões justificadoras da classificação legal. Não há distinção, nesse aspecto, se a Corte utiliza a due process clause ou a equal protection clause na análise do caso, pois irá ser decidido, em ambas as hipóteses, se a liberdade em demanda é importante o suficiente para ser garantida na condição de um direito fundamental. Em regra, se a restrição incorporada na lei alcança direito conferido a todas as pessoas, a due process clause é a cláusula adequada para a análise do caso; e se o direito é negado apenas a um grupo de pessoas, sendo concedido aos demais, a análise deve estar alicerçada na garantia da equal protection clause (CHEMERINSKY, 2006, p. 792-4). Quando se define que o direito negado pela lei é de natureza fundamental, de qualquer sorte os estados devem mostrar não somente a finalidade perseguida pela restrição estabelecida, mas também sua necessidade.

O caso Einsenstadt foi julgado à luz da equal protection clause, em face do caráter nitidamente discriminatório da lei em relação às pessoas solteiras. Distinções relacionadas ao estado civil configuram, sem dúvidas, classificações obscuras, o que desfaz a presunção da garantia da igual consideração perante a lei. Quer dizer, a presunção de que as leis aprovadas pelo critério majoritário não reduzem, de forma injusta, os direitos das minorias deixa de existir, incumbindo ao poder público, em sede de apreciação da constitucionalidade de suas provisões, comprovar que a meta visada não seria alcançada por meio de outras medidas menos invasivas e onerosas no tocante à garantia das liberdades básicas (WENZ, 1992, p. 78 e 75).

A lei de controle de natalidade, em Einsenstadt, foi considerada arbitrária, reputandose desarrazoado o interesse na proteção da saúde ou no impedimento das relações sexuais entre pessoas solteiras ou entre pessoas casadas e solteiras. Negada essa rationale, restava responder se a lei poderia ser legitimada sob o argumento de que a contracepção é em si mesma imoral. A indagação pertinente, nesse particular, é a seguinte: a imoralidade passível de ser atribuída às relações sexuais fora do casamento é do tipo que configure uma imoralidade que possa ser afirmada em uma base pública, ou se trata de questão atinente à vida privada das pessoas? No primeiro caso, os estados estariam autorizados a formular um juízo coletivo acerca da contracepção, impondo as restrições necessárias ao enquadramento das decisões individuais ao conceito adotado. No segundo caso, o conteúdo moral da 


\section{RFD}

contracepção seria algo a ser definido por cada pessoa na consecução do seu planejamento procriativo.

Essa resposta é dada em Griswold, cujo decreto sustentou a admissibilidade da contracepção para as pessoas casadas. Não haveria motivo para enfrentar a questão uma segunda vez. Embora o direito à privacidade tenha sido conferido apenas às pessoas casadas, quanto à matéria apreciada, em última instância o que se sedimentou ali foi a privacidade individual de escolha, pois o casal não configura, em si mesmo, um ser autônomo, mas uma união entre duas pessoas, tendo cada uma delas personalidade independente, nos planos emocional e intelectual. Se, para as pessoas casadas, o acesso à contracepção é uma emanação do direito à privacidade, não havendo, assim, fundamento para a sua proibição, sob o ponto de vista do significado moral da prevenção da gravidez em si, o mesmo raciocínio há de prevalecer para as pessoas solteiras (ESTADOS UNIDOS, Suprema Corte, 1972, p. 4523). Em Eisenstadt, o conceito de privacidade é desfocado do contexto das relações familiares para ser aplicado diretamente à autonomia procriativa, adquirindo o estatuto de um direito individual propriamente dito, tal como fora anteriormente anunciado no caso Skinner (WENZ, 1992, p. 28). Restringir o acesso ao planejamento procriativo simboliza um ato ainda mais invasivo, em termos de privacidade, do que restringir a prática do aborto, porque impede o exercício do controle sobre o próprio corpo e o direito a ter relações sexuais sem assumir obrigatoriamente o risco de gravidez.

No que concerne ao envolvimento das cláusulas constitucionais no tema da contracepção, o aspecto mais interessante, no caso Einsenstadt, é o da interação entre liberdade, enquanto privacidade, e igualdade, apesar de ainda não se colocar em pauta a perspectiva do gênero. De qualquer sorte, sob o prisma da garantia da igual liberdade, para se restringir o direito ao controle de natalidade de uma classe específica de pessoas seria preciso que o critério para essa diferenciação estivesse intimamente relacionado ao objetivo visado pela lei, e, ainda, que esse objetivo constituísse justificativa plausível para o banimento do acesso das pessoas solteiras à contracepção (ESTADOS UNIDOS, Suprema Corte, 1972, p. 487). Ocorre que nenhum dos requisitos exigidos por essa diretiva interpretativa foi preenchido pelos argumentos dos apelados.

A análise da cláusula da igual proteção, entretanto, foi extremamente superficial. Apenas o juiz Brennan deu a ela maior destaque. Os demais votos concorrentes mantiveram o foco na liberdade de expressão da Primeira Emenda, aplicável aos estados em razão da 


\section{RFD}

Décima Quarta Emenda. O juiz Douglas chegou a dizer que o caso Einsenstadt se resume a esse ponto (ESTADOS UNIDOS, Suprema Corte, 1972, p. 455), já que se trata simplesmente de justificar ou não a atitude do apelado de entregar o produto à terceira pessoa, diante da circunstância de que ele não era profissional autorizado a prescrever o tipo de medicamento em questão. Esse estreitamento argumentativo se deve, em parte, ao fato de que a lei apreciada proibia a distribuição e não o uso de contraceptivos, motivo pelo qual os julgadores preocuparam-se mais com a investigação relativa à aceitabilidade da conduta do condenado, a fim de reverter sua condenação, e não o com o interesse de todas as pessoas, sem distinção, ao acesso a métodos de prevenção da concepção.

Em termos gerais, a Suprema Corte ainda não conseguiu definir parâmetros exatos para o controle da ação dos estados em matérias de caráter supostamente discriminatório. Não se elaborou, com maior clareza, se os limites das classificações legais são ou não idênticos quando se trata, por exemplo, de diferenciações por motivo de raça, religião, nacionalidade ou pensamento político. A doutrina do controle constitucional sobre as normas classificatórias desenvolveu-se mais, no tocante ao tema da discriminação racial, e, assim mesmo, com uma certa obscuridade no que concerne ao padrão da equal protection clause. Presume-se, regra geral, que as premissas básicas para conter a atuação legislativa dos estados, ainda sendo estáveis e universais, podem ser aplicadas de modo diferenciado de acordo com as circunstâncias específicas do caso. Como utilizar essa doutrina na esfera dos direitos reprodutivos das mulheres"? (BROWN et al, 1971, p. 905-6). Trata-se de uma seara a ser adensada pela Suprema Corte, com a contribuição marcante das premissas estabelecidas pelas teorias feministas, que vêm sendo aperfeiçoadas na qualidade de um dos paradigmas de constitucionalidade, na garantia do direito ao aborto.

No entanto, apesar da densidade dos argumentos introduzidos pela análise da igualdade de gênero no sistema norte-americano, não serviria muito, em termos constitucionais, substituir a substantive due process clause pela equal protection clause enquanto categoria fundamental para assegurar a efetividade dos direitos reprodutivos, pois a classificação por motivo de gênero é admissível com base no padrão do escrutínio intermediário. À luz da equal protection clause, o interesse do governo na preservação da moralidade tradicional ou na proteção da vida potencial, no caso do aborto, viria a ser considerado legítimo mediante a simples alegação de tratar-se de um objetivo importante dos estados, embora não necessário ou premente. Quer dizer, a análise da constitucionalidade da 
regulação pública da contracepção e do aborto segue critérios assemelhados, seja aplicandlo-

se a due process clause, seja aplicando-se a equal protection clause (CHEMERINSKY, 2006, p. 824). ${ }^{16}$ Em Einsenstadt, foi seguido o padrão da strict scrutiny porque a discriminação, nas circunstâncias apreciadas, não dizia respeito à classificação de gênero e sim, como visto, à injustificável classificação baseada no estado civil das pessoas.

A decisão em Einsenstadt foi significativa, tanto em relação ao tema da contracepção quanto em relação ao tema do aborto, não só porque universalizou o direito ao acesso à contracepção, rompendo com o conteúdo restritivo do julgamento do caso Griswold, que, como se sabe, assegurou esse direito somente às pessoas casadas. Além disso, o que é ainda mais significativo, Einsenstadt forneceu fundamento para ampliar o alcance do direito à privacidade, no sentido de não mais aplicar-se exclusivamente à contracepção, mas igualmente à interrupção da gestação (WARREN, 2009, p. 223). ${ }^{17}$ A garantia do acesso à prevenção da concepção tem por motivação principal acautelar a liberdade de ter relações sexuais sem o risco de gerar uma criança. Para as mulheres solteiras, em especial, essa liberdade envolve a definição do momento adequado para o projeto da maternidade. Como pontuado por Laurence Tribe, a decisão Roe v. Wade seguiu primordialmente os passos interpretativos desses dois precedentes que regulamentaram o direito à contracepção, Griswold v. Connecticut e Einsenstadt v. Baird (TRIBE, 1990, p. 94).

\section{A INCLUSÃO DO DIREITO AO ABORTO NA CARTA DE DIREITOS (BILL OF RIGHTS): PRIVACIDADE PESSOAL, MARITAL, FAMILIAR E SEXUAL}

A Suprema Corte manteve o caráter fundamental do direito de privacidade ao apreciar a inconstitucionalidade de uma lei criminal do Estado do Texas, que proibia o aborto a não

\footnotetext{
${ }^{16}$ No mesmo sentido, ressaltando que a articulação da equal protection clause na fundamentação do aborto não teria o condão de assegurar o escrutínio rígido como padrão de análise das restrições dos estados, consulte-se SMITH, Priscilla J. Give justice ginsburg what she wants: using sex equality arguments to demand examination of legitimacy of state interests in abortion regulation. 34 Harvard Journal of Law \& Gender 377, Summer 2011, p. 406-7.

17 A autora refere-se à seguinte afirmação do juiz Brennan: "if the right of privacy means anything, it is the right of the individual, married or single, to be free from unwarranted governmental intrusion into matters so fundamentally affecting a person as the decision whether to bear or beget a child" (Einsenstadt, p. 453). Tradução livre: "se o direito de privacidade significa alguma coisa, é o direito do indivíduo, casado ou solteiro, de estar livre de uma intrusão governamental não autorizada em matérias que afetam tão fundamentalmente a pessoa, como a decisão de sustentar ou gerar uma criança". De fato, como bem salientado pela autora, o padrão da proteção máxima conferida a esse tipo de decisão, nos termos do pronunciamento do juiz Brennan, permite aplicar o direito de privacidade ao aborto, o que efetivamente foi feito em Roe $v$. Wade.
} 


\section{RFD}

ser na hipótese em que fosse necessário para salvar a vida da gestante. A ação foi movida por uma mulher solteira, no ano de 1970, sob a alegação de que gostaria de interromper sua gestação em condições seguras e de que seu direito de privacidade estaria protegido pelas Primeira, Quarta, Quinta, Nona e Décima Quarta Emendas constitucionais. Trata-se do caso Roe v. Wade (ESTADOS UNIDOS, Suprema Corte, 1973), conhecido como sendo o mais complexo e controverso dentre todos aqueles relacionados às liberdades individuais.

Para sustentar a extensão do conceito normativo de privacidade ao direito de interrupção voluntária da gravidez, a Suprema Corte partiu dos demais direitos assegurados em seus precedentes, no que concerne à preservação da vida íntima das pessoas. Conforme já explicitado, nesses precedentes foi sedimentada a perspectiva de que a categoria genérica da liberdade inserida na Bill of Rights assegura, implicitamente, a não interferência dos estados nas decisões referentes às relações conjugais e familiares, à criação e educação dos filhos, à procriação e à contracepção (ESTADOS UNIDOS, Suprema Corte, 1973, p. 152-3).

Em linhas gerais, a Corte retomou, em Roe, a doutrina da substantive due process clause, discutida, sobretudo, em Griswold, para declarar que a proteção da privacidade abrange o direito ao aborto, por meio da Décima Quarta Emenda. O juiz Stewart acentuou que a Constituição não contém provisões específicas concernentes à intimidade no casamento e nas relações familiares, não sendo possível, portanto, evitar, no tema do aborto, a adoção do conceito amplo de liberdade, na forma prevista na Décima Quarta Emenda (ESTADOS UNIDOS, Suprema Corte, 1973, p. 167-8). ${ }^{18}$ A opinião de Tribe dá inteiro suporte a este entendimento. Como já mencionado, para o autor a due process clause da Décima Quarta Emenda exige uma construção jurisprudencial, tendo sido, desde o seu estabelecimento, também compreendida como uma categoria substantiva em matéria de direitos individuais (TRIBE, 1990, p. 83-4).

Considere-se, porém, que a atribuição de tamanha abrangência ao conceito de privacidade não é isenta de dificuldades e não atende satisfatoriamente o propósito de caracterizar o aborto como um direito fundamental protegido pela Décima Quarta Emenda, embora isso tenha sido sustentado em Roe $v$. Wade. Afigura-se problemático, por exemplo, o argumento de Tribe, segundo o qual a existência da vida do embrião, ou feto, não retira o

\footnotetext{
${ }^{18}$ Saliente-se que, ao defender a aceitabilidade do sentido substantivo da due process, Stewart modificou a posição que assumiu no caso Griswold, no qual entendeu não cabível a mesma cláusula (Griswold, 1965, p. 528).
} 


\section{RFD}

caráter "privado" da decisão da gestante. Esta visão deixa à margem do debate o fato de que

o aborto importa não apenas no direito ao livre controle sobre a gestação, mas envolve, de maneira controversa, a destruição do feto. Sem levar em conta tal circunstância, a solução da questão parece simples, pois basta argumentar que o caso do aborto não se distingue, no tocante às categorias jurídicas a ele aplicáveis, dos casos relacionados à contracepção. Tribe chega a dizer que uma eventual reversão do caso Roe exigiria também a reversão do caso Griswold. Do contrário, a Corte teria que traçar uma linha divisória entre o direito das mulheres de evitar a gravidez e a desintegração do seu direito de interrompê-la logo após a fertilização do óvulo, o que, para o citado autor, somente seria possível pela afirmação de que o embrião possui direitos próprios desde a concepção (TRIBE, 1990, p. 96, 98, 101 e 115). ${ }^{19}$

Mas não é bem assim, pois a demarcação da linha divisória mencionada por Tribe poderia se centralizar no valor moral do nascituro, mesmo não se pressupondo sua personalidade como sujeito de direitos. Basta lembrar a distinção operada por Dworkin entre a condição da pessoa humana, como titular do direito à vida, e a condição do nascituro, cuja dignidade moral pode ser protegida em razão do significado intrínseco da vida. ${ }^{20} \mathrm{~A}$ decisão em Roe firma expressamente essa interpretação, quando declara que o fato de o nascituro não ser pessoa, em termos constitucionais, não fornece uma resposta completa para legitimar o aborto. O sentido substantivo da liberdade (Décima Quarta Emenda), sem o recurso a raciocínios adicionais, não responde à tese apresentada pelo Estado de Texas de que a vida tem início no momento da concepção. A Corte precisou investigar se o governo tem ou não um interesse convincente na tutela da vida em si mesma (ESTADOS UNIDOS, Suprema Corte, 1973, p. 159). Algo mais tinha que ser dito em relação à aplicação da Décima Quarta Emenda ao caso do aborto. Nessa direção, a Corte articulou o argumento de que o sistema legal como um todo, excetuando-se a lei que criminaliza o aborto, não endossa a garantia da

\footnotetext{
${ }^{19}$ Em outra linguagem, RUBENFELD, Jed. On the legal status of the preposition that "life begins at conception". 43 Stanford Law Review, February 1991, p. 603, apoia esse entendimento, quando pondera não haver razão para diferenciar o aborto da contracepção, em termos de proteção constitucional, considerando a ausência de determinação constitucional prévia sobre o estatuto da vida nascitura.

${ }^{20}$ Esclareça-se que, segundo Dworkin, existem dois distintos interesses que podem ser tutelados pelo estado no que concerne à preservação da vida: de um lado, uma pretensão derivada do direito à vida, aplicável às pessoas, e de outro lado uma pretensão destacada, desvinculada da proteção direta desse direito e fundamentada na ideia de sacralidade da vida. Para o autor, o desacordo em torno do aborto se fundamenta, na realidade, no apelo à segunda pretensão (destacada) e não à primeira (derivada), tratando-se de uma controvérsia moral e não biológica (Confira-se, nesse sentido, DWORKIN, Ronald. Life`s dominion: an argument about abortion, euthanasia and individual freedom. New York: Vintage Books, 1994, p. 11 e 13-4, 22-3 e 68-9.
} 


\section{RFD}

vida antes do nascimento. Construiu-se, nessa base, o entendimento de que o interesse convincente dos estados de preservar a vida potencial somente se configura a partir da viabilidade fetal. Depois desse ponto, como declarado pela opinião majoritária, a tutela do feto é justificável sob os prismas lógico e biológico (ESTADOS UNIDOS, Suprema Corte, 1973, p. 161 e 163).

O posicionamento adotado, no tocante aos direitos da vida pré-natal, é o aspecto mais turbulento da decisão Roe v. Wade. A Corte preferiu não se pronunciar sobre a definição do início da vida, salientando, contudo, que as leis, em regra, atribuem direitos aos não nascidos somente em circunstâncias estritamente delimitadas e, assim mesmo, sua efetiva aquisição pressupõe o nascimento com vida. Por outro lado, a decisão não é omissa na determinação do início da tutela da vida nascitura. Ao contrário, o conhecido padrão trimestral, então elaborado, é bastante claro. Determinou-se o seguinte: a) no primeiro trimestre da gestação, a escolha deve ficar ao encargo da mulher e do seu médico; b) no segundo trimestre, os estados estão autorizados a regulamentar o aborto exclusivamente para a proteção da saúde da gestante; c) no terceiro trimestre, os estados podem regulamentar e até mesmo proibir o aborto em vista do seu legítimo interesse na proteção da vida humana potencial (ESTADOS UNIDOS, Suprema Corte, 1973, p. 159, 161 e 164-5). Desse modo, antes da viabilidade fetal, os estados não podem restringir o aborto com base na alegação de que têm interesse na proteção da vida do nascituro. Não está incluído nos poderes dos estados a possibilidade de determinar que o nascituro tem personalidade jurídica ou que a vida começa na concepção.

Quando a gestação envolve riscos à vida ou à saúde da mulher, o procedimento do aborto pode ser feito a qualquer tempo. Não havendo riscos, o critério é o da viabilidade fetal. Em Roe, a questão foi posta sob um ângulo pragmático. A ideia inicial do juiz Blackmun era garantir o aborto somente no primeiro trimestre de gestação, mas outros juízes acolheram a ideia de que muitas mulheres, sobretudo as mais pobres, não teriam condições de se decidirem em tão curto tempo. Por essa razão, resolveram fixar o prazo máximo de 28 semanas de gestação para a realização do aborto. A regra foi elaborada de acordo com um critério razoável de justiça na visão dos magistrados. Entendeu-se que a mulher que não faz a sua escolha até a viabilidade fetal consentiu tacitamente com a autoridade do governo de intervir na regulamentação de sua conduta, em vista do estágio adiantado do desenvolvimento fetal. Simplesmente traçou-se uma linha divisória, sopesando-se que não é necessário assegurar o aborto durante toda a gestação na hipótese de ser realizado por 


\section{RFD}

decisão da mulher, ou seja, não por prescrições médicas, bastando conceder-lhe um prażo suficiente, em igualdade de condições, para, tendo ciência do seu estado, realizar ou não o procedimento (BALKIN, 2014, p. 345). ${ }^{21}$

Nesses contornos, a Suprema Corte assumiu o estatuto fundamental do direito ao aborto à luz da abordagem da due process clause feita em Griswold. O poder dos estados de regulamentar o aborto, em decorrência do seu interesse na tutela da vida pré-natal foi delimitado sob o prisma do padrão do strict scrutiny. A origem dessa compreensão, como esclarecido no julgamento, está na própria definição constitucional do termo "pessoa", que não inclui, no sentido da Décima Quarta Emenda, o nascituro. Foi também rejeitado o argumento de que a restrição da lei visava proteger a saúde das mulheres, considerando que, conforme indicações médicas seguras, os riscos do procedimento, nos dois primeiros trimestres da gestação, são menores do que os riscos do próprio parto (ESTADOS UNIDOS, Suprema Corte, 1973, p. 153, 155-8 e 170).

Por outro lado, o paradoxo trazido pelo conceito de vida potencial, no que toca à justificação da livre escolha pelo aborto, torna o direito de privacidade um fundamento incompleto, ainda que possa estar incluído, implicitamente, em determinados preceitos da Bill of Rights. Em linhas gerais, o apelo à privacidade, embora satisfatoriamente aplicável à proteção do direito ao uso de contraceptivos, não é forte o bastante para justificar a decisão de interromper a gestação, sendo necessária uma revisita ao paradigma estabelecido em Roe.

Saliente-se aqui a posição de Peter Wenz, segundo a qual a privacidade, na forma sustentada em Griswold e invocada em Einsenstadt e Roe, não é parâmetro adequado para a proteção do aborto, e não se compatibiliza com outras interpretações construídas pela Suprema Corte em casos nos quais o conceito de privacidade estava em discussão. Esclareçase que a rationale escolhida pelo citado autor é oposta à de Lawrence Tribe, por rejeitar o padrão da due process clause, em sentido substantivo, e contrapor-se ao recurso aos direitos não enumerados, que, em sua opinião, atribuem poder excessivo aos juízes. Para Wenz, as cláusulas específicas da Constituição, expressamente mencionadas, são aplicáveis independentemente da utilização das cláusulas abstratas (WENZ, 1992, p. 36, 17, 47-8, 99 e

\footnotetext{
${ }^{21}$ É pertinente enfatizar que conforme DWORKIN, Ronald. Freedom's law: the moral reading of the American Constitution. Cambridge, Massachussets: Harvard University Press, 1996, p. 114-5, a justificativa para que o governo esteja autorizado a regulamentar e até proibir o aborto após seis meses de gravidez reside justamente no argumento de que até esse tempo a gestante teve tempo suficiente para agir com autonomia, sem nenhum tipo de interferência externa.
} 
103). Em realidade, Wenz não aceita, no caso Roe, nem a justificativa do Juiz Blackmún (privacidade), nem a do Juiz Stewart (liberdade da due process clause). Nesse ponto, esclareça-se que a Suprema Corte, nos casos que se seguiram a Roe $v$. Wade, terminou reduzindo gradualmente a utilização da categoria da privacidade. Em contrapartida, o conceito da substantive due process clause passou a receber maior extensão, indicando-se, claramente, o crescimento da importância dessa cláusula na declaração dos direitos fundamentais não expressos (GREENE, 2010, p. 724-5). É plausível defender, nessa seara, que a doutrina da incorporação (Juiz Black), utilizada no caso Griswold e já antes explicitada, dá margem a que se reelabore a aplicação do princípio genérico da liberdade (Décima Quarta Emenda) ao caso do aborto, de forma a conectá-lo a uma cláusula constitucional específica, também relacionada às liberdades básicas.

Nenhuma reflexão foi feita, no caso Roe, sobre o significado dos direitos previstos nas demais emendas constitucionais. Até mesmo o voto do juiz Rehnquist, dissidente, pressupôs a consideração exclusiva da Décima Quarta Emenda para a solução do caso, sendo que sua oposição ao entendimento majoritário consistiu unicamente na arguição do caráter não absoluto da liberdade. No seu sentir, a proibição do aborto estaria dentro dos poderes legítimos dos estados de elaborar leis compatíveis com seus interesses, o que somente extrapolaria os critérios de razoabilidade, se a proibição se estendesse à hipótese de salvamento da vida da gestante (ESTADOS UNIDOS, Suprema Corte, 1973, p. 172-3).

A excessiva confiança da Corte na concretização da autonomia procriativa com base no conceito de liberdade da due process clause abriu o caminho para o criticismo posterior em relação ao paradigma da decisão Roe $v$. Wade. O juiz Rehnquist chamou a atenção para esse fato, ao ponderar que a transposição do padrão do interesse convincente dos estados (strict scrutiny) para a due process clause da Décima Quarta Emenda poderia trazer maior confusão para a interpretação das leis (ESTADOS UNIDOS, Suprema Corte, 1973, p. 173). ${ }^{22}$ Não parece consistente esse raciocínio, pois é essencial a utilização de um critério rígido no balizamento das motivações dos estados na regulamentação dos direitos reprodutivos. $\mathrm{O}$ strict scrutiny, aliás, nunca deveria ter sido abandonado pela Suprema Corte na apreciação

\footnotetext{
${ }^{22}$ Nessa passagem do seu voto, o magistrado esclarece que o modelo do strict scrutiny foi concebido, no âmbito jurisdicional, para a apreciação das leis cujo conteúdo remete à equal protection clause, também da Décima Quarta Emenda. Aplicar o mesmo modelo à due process clause, como de fato fez a Corte em Griswold e Roe, não é, em sua opinião, estratégia adequada, por extrapolar a moldura do poder de controle normativo das ações dos estados, em conformidade com a concepção original dos autores da Constituição.
} 
das leis restritivas da prática do aborto, como se deu no julgamento do caso Planned

Parenthood of Southeastern Pennsylvania v. Casey (ESTADOS UNIDOS, Suprema Corte, 1992). ${ }^{23}$

O maior problema consistiu em sustentar, na condição de fundamento único do aborto e da contracepção, a noção de privacidade familiar e procriativa extraída da due process clause em sentido substantivo. No julgamento Roe v. Wade, a Corte não teve a percepção de que o conteúdo da autonomia procriativa abrange mais do que a simples garantia da liberdade, em sentido abstrato, contra a coerção estatal, no que pese a densa discussão prévia, travada nos casos Griswold e Einsenstad, sobre os requisitos da cláusula do devido processo legal. Não inserir, de forma clara, na fundamentação constitucional do aborto, a consideração dos direitos básicos definidos na Primeira Emenda, em particular a liberdade religiosa, gerou uma certa instabilidade na proteção assegurada em Roe. Passou despercebido o questionamento que o juiz Stewart já havia feito em Griswold quanto a não arguição da cláusula da "proibição do estabelecimento da religião" (establishement clause) como base constitucional para a liberdade de utilização de métodos anticonceptivos (ESTADOS UNIDOS, Suprema Corte, 1965, p. 528-9). ${ }^{24}$

Em outra dimensão, a não abordagem da perspectiva da igualdade de gênero também reduziu a abrangência do esquema constitucional que, em sua integralidade, legitima a autonomia procriativa. Nesse ponto, perdeu-se a oportunidade de avançar na interpretação do envolvimento da equal protection clause na efetivação dos direitos reprodutivos. O único caminho vislumbrado pelos julgadores, em Roe, diante do histórico dos seus precedentes, foi o da vinculação do tema do aborto ao da contracepção. Essa rota, como não poderia ser diferente, foi objeto de crítica ardorosa por parte das doutrinas feministas, que rejeitam totalmente o parâmetro do direito de privacidade, sob o argumento de que a presunção da autonomia decisória das mulheres, na esfera íntima, é um grande equívoco. Como acentuado por Catharine Mackinnon, ao situar a autonomia procriativa como uma matéria referenciada

\footnotetext{
${ }^{23}$ Essa decisão fortaleceu significativamente os poderes dos estados na criação de obstáculos à realização do aborto, enfraquecendo e até revertendo parcialmente a decisão Roe. Não poremos em análise os padrões adotados na decisão em Casey, haja vista a finalidade estrita do presente artigo de investigar apenas o processo interpretativo que conduziu à permissão do aborto no país.

${ }^{24}$ A establishement clause caracteriza um dos sentidos da liberdade religiosa da Primeira Emenda, e se consubstancia na proibição da adoção por parte dos estados de uma doutrina religiosa específica, seja expressamente, seja através do acolhimento normativo dos seus preceitos. Quanto ao envolvimento dessa cláusula na proteção do direito ao aborto, como defendido por muitos intérpretes, não há espaço, igualmente, neste trabalho, para a exposição dos respectivos argumentos.
} 


\section{RFD}

à vida privada, a Corte deixou de lado a complexidade das relações de gênero, contribuindo, assim, para escamotear o processo cultural de violação dos direitos das mulheres (MACKINNON, 1991, p. 185, 187-8, 192, 216 e 224). Entretanto, esse enfoque não estava ainda amadurecido no tempo da decisão Roe, quando se entendia que a mulher não carecia de uma tutela especial e que qualquer remissão ao princípio da igualdade sexual significaria não uma medida contra a discriminação baseada no gênero, mas antes uma "ação afirmativa" ("affirmative action") (MACKINNON, 1991, p. 234), um benefício social não articulável na condição de uma função normativa justificadora do dever positivo de proteção do Estado.

\section{O VALOR DA VIDA PRÉ-NATAL E A AUTONOMIA MORAL DA GESTANTE NA REGULAMENTAÇÃO DO DIREITO AO ABORTO: CONTORNOS PRECISOS ÀS LEGISLATURAS ESTADUAIS E À JUDICIAL REVIEW}

Grosso modo, o paradigma do pluralismo ideológico impede que o poder público imponha às mulheres, na qualidade de agentes morais e políticos, qual o valor deve ser atribuído à vida nascitura nos primeiros estágios do seu desenvolvimento. Esse entendimento foi legitimado na decisão Roe $v$. Wade a partir da interpretação que foi dada à categoria da liberdade da Décima Quarta Emenda, não no sentido de privacidade na vida íntima, mas no sentido de autonomia procriativa. Ressalte-se que, embora o julgamento, no caso, tenha se centrado no direito à privacidade, a fundamentação constitucional acolhida importou na afirmação implícita da liberdade como autonomia moral, na medida em que o poder de decisão sobre o destino da gestação, em seus dois primeiros trimestres, envolve diretamente a independência ética da gestante no tocante à importância a ser atribuída à vida pré-natal.

Os defensores do direito de personalidade do nascituro costumam alegar que o sistema constitucional norte-americano não confere à Suprema Corte autoridade absoluta para declarar o momento a partir do qual a vida tem início, bem como a quem, ou quais entidades, assegurar o direito à vida. De acordo com essa visão, o papel do poder judiciário, no modelo federalista, não inclui a faculdade de definir o conteúdo das leis, e, em particular, o valor da vida nascitura. Se assim o fosse, afirmam alguns autores, as restrições originariamente impostas à autoridade pública federal, na interpretação da Constituição, seriam esvaziadas, o que representaria a negação da autonomia dos estados (CRAMPTON, 2012, p. 304-5). 
Essa linha de argumentação não é razoável sob o aspecto da teoria constitucionalista,

base do sistema judicial do país. A posição sustentada em Roe, no sentido de que a vida do nascituro não é tutelável, em caráter absoluto, nos termos da Décima Quarta Emenda, se compatibiliza com a divisão de poderes, em sua concepção original, entre o governo federal e os estados. Além disso, assenta um parâmetro moderado para equilibrar o interesse público e a autonomia procriativa, porque não rejeita a discricionariedade governamental na proteção da vida potencial, pressupondo-a, inclusive, na justificativa de uma delimitação diferenciada do poder interventivo dos estados em cada etapa do processo gestacional. Nesse particular, Dawn Johnsen explica que a consideração dos interesses fetais em Roe reflete a possibilidade de que os estados estabeleçam suas políticas, no que diz respeito à tutela da vida potencial, desde que as mesmas não infrinjam os direitos das mulheres de interrupção da gestação ou os contornos da proteção constitucional de sua independência moral e intelectual (JOHNSEN, 1986, p. 614). ${ }^{25}$

\footnotetext{
${ }^{25}$ Interessante ressaltar, nesse ponto, a título comparativo, que também no Brasil se discute acerca dos limites de intervenção dos poderes legislativo e judiciário na regulamentação dos interesses do nascituro e do direito da mulher à interrupção da gestação. Como se sabe, o direito, nos Estados Unidos da América, alicerça-se, desde os seus primórdios, no sistema da common law, sedimentado na primazia da Constituição sobre os poderes do Parlamento, na doutrina dos precedentes e no pragmatismo jurídico. Nesse sentido, o direito constitucional desenvolveu-se, no país, não tanto através do trabalho doutrinário, e sim através da atividade judicante dos tribunais, em especial, da Suprema Corte. O Brasil, diferentemente, segue o modelo da civil law, recepcionado no início do império português. No entanto, o Brasil vem mitigando, ao longo da história, as características desse modelo, na tentativa de construir, no contexto do julgamento dos casos concretos, um esquema interpretativo sustentado na supremacia da Constituição em relação às leis infraconstitucionais. A introdução do controle concentrado (direto) de constitucionalidade no ano de 1965, por meio de Emenda à Constituição de 1946, possibilitou o decreto de nulidade das leis, com efeitos erga omnes e vinculantes. A Constituição de 1988 adota o princípio da "justicialidade" (art. 5, inciso XXXV), que tem sua raiz no sistema da rule of law, caracterizado pela submissão da discricionariedade dos atos promulgados pelas autoridades políticas ao poder decisório dos juízes em matérias que envolvam lesão a direitos individuais. Por fim, mencionese que a discussão sobre o aborto, no Brasil, se aprofundou nos últimos anos. Tramita no Congresso Nacional a PEC 181, propondo o endurecimento das regras penais, com a criminalização do aborto até mesmo nas hipóteses atualmente permitidas - salvar a vida da gestante, estupro e anencefalia - sob o argumento de que o direito à vida tem início no momento da concepção (ver matéria publicada no site: http://www.jb.com.br/pais/noticias/2017/11/23/pec-que-proibe-aborto-em-caso-de-estupro-causa-polemica/).

Por outro lado, a tendência à ampliação das hipóteses do direito ao aborto, igualmente, está se desenvolvendo, com o debate em torno dos casos de microcefalia e a partir de algumas decisões do STF, como no caso do HC 124.306, no qual o ministro Luís Barroso declarou que os artigos 124 a 126 do CP, que punem a prática do aborto, devem se submeter a uma interpretação conforme a Constituição, a fim de permitir a interrupção da gestação, durante seu primeiro trimestre, sob pena de violação dos direitos fundamentais da mulher. Em outro caso, em ação proposta pelo PSOL, uma mulher, com 12 semanas de gestação e já com dois filhos, peticionou ao STF, pleiteando o direito de realizar o aborto. A ministra Rosa Weber negou a liminar, afirmando que não se pode resolver o caso de apenas uma gestante. A ação, ainda, irá para julgamento no plenário da Corte. Vê-se, assim, que o tema avança em mão dupla - atuação política dos parlamentares e atuação revisional do STF - em uma estrutura assemelhada, em parte, ao direito americano.
} 


\section{RFD}

Nos Estados Unidos, o principal objetivo das leis estaduais, que perseguem a garantia da personalidade fetal é tentar preencher o que ficou sem resposta na decisão Roe, a definição do início da vida. Dissociar o conceito de personalidade da constatação de que a vida humana potencial existe desde a concepção não foi suficiente para isentar a perspectiva da privacidade e da autonomia procriativa do criticismo subsequente, enraizado nos interesses fetais. É necessário, então, que a Suprema Corte reformule o modelo argumentativo traçado no caso Roe e afirme, claramente, que o status moral da vida pré-natal não equivale ao status moral das mulheres gestantes. Isso pode representar um novo fundamento constitucional para a proibição do aborto, além de pacificar o entendimento de que se trata de um assunto cuja concretização é papel do poder jurisdicional, em sede federal, no exercício da judicial review, não sendo o caso de retornar para o âmbito de apreciação das legislaturas estaduais. ${ }^{26}$

Quando se pensa na função constitucional da Suprema Corte americana, no tocante à definição de restrições aos direitos fetais, o referencial adotado não é o conceito do início da vida potencial, em sua dimensão biológica. O exercício da autoridade jurisdicional circunscreve-se à concretização, na esfera jurídica, do âmbito de proteção da vida potencial, sendo, nesse aspecto, legítimo.

A despeito disso, alguns estados apresentaram, a partir da década de 2000, projetos de emenda constitucional cujo objetivo é a afirmação do direito à vida do nascituro desde a concepção. Outros estados efetivamente promulgaram leis conferindo ao nascituro algumas garantias na área criminal, contra atos de terceiros, e de direito de família, contra abusos e negligência por parte dos genitores. Além disso, parte dessas leis legitima o dever de proteção à personalidade fetal, o que vem chegando cada vez mais à Suprema Corte, já com algumas decisões que não são, estritamente falando, adequadas às diretivas firmadas em Roe.

Em linhas gerais, as propostas legislativas dos estados, que reivindicam o reconhecimento da proteção da vida do nascituro, em contraposição à decisão Roe, são, notavelmente, inconstitucionais e ilegítimas. De toda sorte, as leis estaduais, para produzirem efeitos, dependem da aprovação majoritária dos respectivos eleitores, o que se realiza através de dois processos de democracia direta regulamentados no país: a) initiative (petição proposta, mediante assinaturas, pelos próprios cidadãos); e b) referendum (votação). A rigor,

\footnotetext{
${ }^{26}$ Ver, em sentido, contrário, DUNAWAY Rita M. The personhood strategy: a state's prerogative to take back abortion law. 46 Willamette Law Review, Winter 2011, p. 343, 348, 351 e 353.
} 


\section{RFD}

a democracia direta tem sido historicamente utilizada pelos estados, desde os anos 70, para restringir a admissibilidade do aborto. ${ }^{27}$

Delegar às instâncias político-representativas a regulamentação do tema, sob o argumento de que uma atuação não "minimalista" (minimalist) do Estado poderia melhor assegurar os interesses das mulheres, não conduziria a resultados positivos. Robin West formula a ideia de uma "justiça reprodutiva" (reproductive justice) que, no seu sentir, justificaria a construção de um padrão de análise menos individualista na definição do direito ao aborto (WEST, 2009, p. 1396-7). Entretanto, ao contrário do defendido por Robin, não há injustiça alguma no padrão jurisprudencial da privacidade, no sentido de autonomia moral, em matéria de escolha reprodutiva. As mulheres não devem ser vistas como seres incapazes de se responsabilizar por seus atos, por isso o aborto deve ser legitimado, em parâmetros constitucionais, como uma escolha aceitável em caso de falha no uso de métodos contraceptivos. A visão político-legislativa tende a focar-se, prioritariamente, no significado moral-coletivo da vida potencial e não na autonomia-dignidade da mulher.

As disposições das legislaturas estaduais, segundo as quais ao nascituro se confere o status de pessoa, não se coadunam com a estrutura do direito à vida, explicitada na Quinta e na Décima Quarta Emendas, o qual se fundamenta no significado substantivo da due process clause e no conteúdo da equal protection clause. Acentue-se, para melhor compreensão do leitor, que na Quinta Emenda, antes da menção à due process clause, a Constituição prescreve que "nenhuma pessoa" (any person) pode ser forçada, em processo criminal, a prestar testemunho contra si próprio. Pela própria natureza da questão inserida no texto e pela linguagem dos constituintes originários, há um entendimento intuitivo que denota a não inclusão do nascituro também no conceito de pessoa veiculado por essa Emenda. Nenhum dos juízes em Roe, nem mesmo os dissidentes, fizeram referência à doutrina da personalidade do feto, exatamente devido à dificuldade de se vislumbrar na Constituição, especialmente nas Emendas direcionadas à titularidade dos direitos fundamentais, qualquer noção capaz de

\footnotetext{
${ }^{27}$ Cf. CARTER, Molly E. in Regulating abortion through direct democracy: the liberty of all versus the moral code of majority, 91 Boston University Review, Janeiro 2001, p. 306-9 e 312-15. Para um aprofundamento sobre o conteúdo dos mencionados projetos e normas legislativas, consulte-se MATAMBANADZO, Saru M. Embodying vulnerability: a feminist theory of the person. 20 Duke Journal of Gender Law \& Policy, fall 2012, p. 57; LOTIERZO, Amy. The unborn child, a forgotten interest: reexamining roe in light of increased recognition of fetus rights. Temple Law Review, Spring 2006, p. 281, 290-1 e 303; e NELSON, Erin. Law, police and reproductive autonomy. Oxford: Oxford and Portland, Oregon, 2013, p. 122-6.
} 


\section{RFD}

sugerir alguma preocupação com o tratamento dos interesses da vida pré-natal. A questão também não foi levantada nos casos posteriores a Roe sequer pelos juízes declaradamente contrários a que se mantenha sob o poder da Corte Federal a última palavra sobre a proteção constitucional ao aborto (BALKIN, 2007, p. 337).

Além disso, o status moral do nascituro é reconhecido por cada estado de forma diferenciada, o que cria obscuridades na definição de uma direção comum para a abordagem do conceito de personalidade. Se a questão voltasse para o controle das legislaturas estaduais, em alguns estados, as mulheres seriam obrigadas a acatar a visão imposta pelas leis, segundo as quais se presume a igualdade entre pessoas nascidas e não nascidas. Em outros estados, as mulheres, diferentemente, teriam direito a uma convicção própria acerca do valor moral da vida potencial. Nas decisões judiciais das cortes estaduais, igualmente, observa-se a mesma dubiedade e instabilidade na doutrina da personalidade jurídica, pela confusão implementada entre a esfera do direito e a esfera da moralidade pública. Ao aproximar a categoria da personalidade à ideia do valor intrínseco da vida humana, as cortes terminam estabelecendo certos padrões morais, regra geral, os mais aceitos pela comunidade, na condição de regras jurídicas (HARVARD LAW REVIEW ASSOCIATION, 2001, p. 1747, 1755, 1759, 1762 e 1764). Em síntese, ao adotarem e imporem às mulheres uma determinada concepção sobre o valor intrínseco da vida humana, sob as vestes do conceito de personalidade, as leis e decisões estaduais eliminam qualquer nível de concretização da liberdade de consciência, ou liberdade religiosa, no tocante aos direitos reprodutivos.

Todavia, não há dubiedades, no texto constitucional, a respeito do alcance da proteção do direito à vida, razão pela qual não se pode permitir a delimitação da tutela do nascituro de acordo com a compreensão particular de cada estado. A controvérsia existente no tema do aborto deve ser resolvida fora do esquema do federalismo, tendo-se em mente que o direito à vida se aplica somente às pessoas que se enquadram na categoria jurídica da personalidade. Banir o direito ao aborto importaria na classificação das mulheres como pessoas constitucionais parciais, isto é, não em seu significado pleno, em violação à perspectiva da igualdade e também da liberdade (NELSON, 2009, p. 160, 162 e 165). ${ }^{28}$ Em

\footnotetext{
${ }^{28}$ Ver, também, RUBENFELD, Jed. On the legal status of the preposition that "life begins at conception". 43 Stanford Law Review, February 1991, p. 601-2; WARREN, Rachel. Pro (whose) choice: how the growing recognition of a fetus's right to life takes the constitutionality out of roe. 13 Chapman Law Review, Fall 2009, p. 243; e JOHNSEN, Dawn E. The creation of fetus rights: conflicts with women's constitutional rights to liberty, privacy and equal protection. 95 Yale Law Journal, January 1986, p. 620.
} 


\section{RFD}

Roe v. Wade, o fundamento do direito ao aborto foi situado na due process clause, mas, e'm realidade, sua constitucionalidade deriva também de outras garantias, como o princípio da igual cidadania. A consideração da condição inferiorizada da mulher, como cidadã de segunda classe, elaborada pelos teóricos da igualdade de gênero, está presente, indiretamente, na rationale adotada em Roe. Diz-se isso porque a decisão do caso avançou entendimento segundo o qual o controle do governo sobre a gestação é ilegítimo por importar na redução da autonomia moral da mulher (BALKIN, 2007, p. 319-20). Em uma outra linguagem, afirma-se que a due process clause, em sentido substantivo, caracteriza o direito ao aborto como um direito moral da mulher, e isso exatamente porque a garantia de sua liberdade de decisão, no tocante à matéria, integra o princípio da autonomia moral, portanto, da plena cidadania.

Volta-se, assim, à doutrina da inclusão no texto da Décima Quarta Emenda dos direitos fundamentais especificados nas demais emendas, adotada pela Suprema Corte, em matéria reprodutiva, desde a decisão Griswold. É no contexto da análise do conteúdo substantivo da Décima Quarta Emenda que a garantia do pluralismo ideológico na definição do valor da vida pré-natal encontra suas raízes. Entretanto, é necessário acrescentar à decisão Roe, com base na proteção assegurada pela liberdade religiosa da Primeira Emenda, uma determinação judicial no sentido de que o estatuto moral do nascituro não pode ser imposto pelos estados. A partir daí, seria possível demonstrar a não aceitabilidade dos projetos de emendas constitucionais cujo objeto é o reconhecimento da personalidade do nascituro. Como advertiu o juiz Blackmun, se essas emendas fossem aprovadas, a decisão Roe seria automaticamente revertida pelo reconhecimento da aplicação da Décima Quarta Emenda ao nascituro, no tocante ao direito à vida (ESTADOS UNIDOS, Suprema Corte, 1973, p. 156-7).

Uma das estratégias dos proponentes das mencionadas emendas é tentar mostrar que sua aprovação não importaria na reversão do caso Roe, mas apenas na produção de alguns efeitos no que concerne à proteção da vida nascitura, o que seria positivo, segundo essas correntes, até por estimular o debate e promover a diversidade entre os estados. Alega-se que o resgate da autonomia dos estados na regulamentação da matéria, como ocorria antes da decisão Roe v. Wade, não modificaria a admissibilidade do aborto, por tratar-se de um direito solidamente instituído no país como um todo (SCOTT, 2011, p. 233, 244 e 253-4). Todavia, essas considerações não são verossímeis, pois o retorno da discricionariedade dos estados, no caso, não faria outra coisa senão substituir a autonomia das mulheres pela autonomia dos 
estados, banindo a liberdade de consciência individual por meio da precedência de uma concepção moral e religiosa convencional. Como se defende aqui, o valor moral do feto somente pode ser definido coletivamente a partir de certo estágio do processo gestacional.

\section{CONCLUSÃO}

Percebe-se que o direito à privacidade foi a categoria que guiou a constitucionalização do direito ao aborto no sistema norte-americano. A incorporação desse direito teve início nos anos de 1920, no contexto das escolhas familiares afetas à educação dos filhos. Em um segundo momento, nos anos de 1940, o direito à privacidade foi acolhido em questões reprodutivas. Até que nos anos de 1960, foi utilizado como fundamento do direito à contracepção e, nos anos de 1970, como fundamento do direito ao aborto.

Viu-se que a utilização do devido processo legal, em sentido substantivo, deu origem ao reconhecimento de liberdades não enunciadas na Constituição, possibilitando, assim, a criação de uma metodologia de análise, segundo a qual alguns direitos são fundamentais por estarem envolvidos no conteúdo daqueles direitos cuja proteção é expressamente assegurada. Como se explicitou, a expansão do direito à privacidade, desde a abordagem do tema da contracepção até o tema do aborto, lançou padrões determinantes para a defesa de uma interpretação constitucional da categoria da autonomia procriativa.

A proposta de construir uma base constitucional democrática para a legalização do direito ao aborto requer uma interpretação da carta de direitos fundamentais em uma dimensão integrativa. A unidade entre a liberdade e a igualdade é o alicerce da atuação da Corte Constitucional. Além disso, o julgamento do caso Roe v. Wade reforça a convicção de que a análise do direito ao aborto exige a discussão sobre os limites da proteção da vida nascitura em parâmetros jurídicos e laicos. Em rigor, o feto, mesmo não sendo pessoa e não estando protegido pelo direito constitucional à vida, pode possuir interesses passíveis de tutela, sendo esta a questão que deve ser esgotada e definida na abordagem do tema do aborto.

\section{REFERÊNCIAS}


AMAR, Akhil Reed. The Bill of Rights Primer: a Citizen's Guidebook to the American Bill 'of Rights. New York: Skyhorse Publishing, 2013.

BALKIN, Jack M., Abortion and original meaning. constitutional commentary. Vol. 24:291, No. 101, 2007; Yale Law School, Public Law Working Paper No. 128. Disponível em: <http://ssrn.com/abstract=925558>. Acesso em 13 abr. 2014.

BARRON Jerome A. e DIENES Thomas. Constitutional law in a nutshell. Eighth edition. St. Paul: West Publishing Co, 2013.

BROWN Bárbara A, EMERSON, Thomas I, FALK, Gail e FREEDMAN Ann E. The equal rights amendments: a constitutional basis for equal rights for women. 80 Yale Law Journal 871, April 1971.

CARTER, Molly E. Regulating abortion through direct democracy: the liberty of all versus the moral code of majority, 91 Boston University Review, Janeiro 2001.

CRAMPTON, Stephen M. An apologia for personhood. 6 Liberty University Law Review, winter/2012.

DUNAWAY, Rita M. The personhood strategy: a state's prerogative to take back abortion law. 46 Willamette Law Review, Winter 2011.

DWORKIN, Ronald. Freedom's law: the moral reading of the American Constitution. Cambridge, Massachusetts: Harvard University Press, 1996.

DWORKIN, Ronald. Life`s dominion: an argument about abortion, euthanasia and individual freedom. New York: Vintage Books, 1994.

DWORKIN, Ronald. Unenumereted Rights: Whether and How Roe Should be Overruled, 59 University of Chicago Law Review 381, Winter 1992.

ESTADOS UNIDOS. UNITED STATES SUPREME COURT. Lochner v. New York, 198 U.S 45 (1905). Disponível em: <www.supremecourt.gov>. Acesso em 01 fev. 2014.

ESTADOS UNIDOS. UNITED STATES SUPREME COURT. Meyer v. Nebraska, 262 U.S. 390 (1923). Disponível em: <www.supremecourt.gov>. Acesso em 08 out. 2013.

ESTADOS UNIDOS. UNITED STATES SUPREME COURT. Pierce $v$. Society of Sisters of the Holy Names of Jesus and Mary, 268 U.S. 510 (1925). Disponível em: <www.supremecourt.gov>. Acesso em 08 out. 2013.

ESTADOS UNIDOS. UNITED STATES SUPREME COURT. Olmstead v. U.S., 277 U.S. 438 (1928). Disponível em: <www.supremecourt.gov>. Acesso em 08 out. 2013. 
ESTADOS UNIDOS. UNITED STATES SUPREME COURT. Skinner v. State of Okl. ex rel. Williamson, 316 U.S. 535 (1942). Disponível em: <www.supremecourt.gov>. Acesso em 08 out. 2013.

ESTADOS UNIDOS. United States Supreme Court. School District of Abington v. Schempp, 374 U. S. 203 (1963). Disponível em: <www.supremecourt.gov>. Acesso em 01 fev. 2014.

ESTADOS UNIDOS. United States Supreme Court. Griswold v Connecticut, 381 U.S. 479 (1965). Disponível em: <www.supremecourt.gov>. Acesso em 01 fev. 2014.

ESTADOS UNIDOS. United States Supreme Court. Einsenstadt v. Baird, 405 U.S. 438 (1972). Disponível em: <www.supremecourt.gov>. Acesso em 01 fev. 2014.

ESTADOS UNIDOS. United States Supreme Court. Roe v. Wade, 410 U.S. 113 (1973). Disponível em: <www.supremecourt.gov>. Acesso em 23 nov. 2013.

ESTADOS UNIDOS. United States Supreme Court. U.S. v. Windsor, 133 S.Ct. 2675 (2013). Disponível em: <www.supremecourt.gov $\geq$. Acesso em 09 abr. 2014.

ESTADOS UNIDOS. United States District Court, District of Columbia. Klayman v. Obama, Not Reported in F.Supp.2d (2013). Disponível em: <www.dccourts.gov>. Acesso em 08 fev. 2014.

ESTADOS UNIDOS. National Archives, Washington/DC. The constitution of the United States of America at the National Archives.

FINE, Toni M. Introdução ao sistema jurídico Anglo-Americano. São Paulo: WMF Martins Fontes, 2011.

GREENE, Jamal, The so-called right to privacy, 43 U.C. Davis Law Review 715, February 2010. Disponível em: <http://ssrn.com/abstract=1456026>. Acesso em 25 nov. 2013.

HARVARD LAW REVIEW ASSOCIATION. What we talk about when we talk about persons: the language of a legal fiction. 114 Harvard Law Review Association, April 2001.

JOHNSEN, Dawn E. The creation of fetus rights: conflicts with women's constitutional rights to liberty, privacy and equal protection. 95 Yale Law Journal, January 1986.

LOTIERZO, Amy. The unborn child, a forgotten interest: reexamining roe in light of increased recognition of fetus rights. Temple Law Review, Spring 2006.

MACKINNON, Catharine A. Toward a feminist theory of the state. Cambridge/London: Harvard University Press. 1991.

MATAMBANADZO, Saru M. Embodying vulnerability: a feminist theory of the person. 20 Duke Journal of Gender Law \& Policy, fall 2012. 
NELSON, Erin. Law, police and reproductive autonomy. Oxford: Oxford and Portlan'd, Oregon, 2013.

NELSON, Lawrence J. Of persons and prenatal humans: why the constitution is not silent on abortion. Lewis \& Clark Law Review, Spring 2009.

RUBENFELD, Jed. On the legal status of the preposition that "life begins at conception". 43 Stanford Law Review, February 1991.

SCOTT, T. J. Why state personhood amendment should be part of the pro-life agenda. 6 University of St. Thomas Journal of Law \& Public Policy, Fall 2011.

SIEGEL, Reva B. Roe's Roots: the women's rights claims that engendered Roe. Boston University Law Review, [vol. 90:1875), Nov. 8, 2010.

SMITH, Priscilla J. Give justice Ginsburg what she wants: using sex equality arguments to demand examination of legitimacy of state interests in abortion regulation. 34 Harvard Journal of Law \& Gender 377, Summer 2011.

STEVENS, John Paul. The bill of rights: a century of progress. 59 University of Chicago Law Review 13, Winter 1992.

TRIBE, Laurence H. Abortion: the clash of absolutes. New York/London: W. W. Norton \& Company, 1990.

WARREN, Rachel. Pro (whose) choice: how the growing recognition of a fetus's right to life takes the constitutionality out of roe. 13 Chapman Law Review, Fall 2009.

WENZ, Peter. Abortion rights as religious freedom. Philadelphia: Temple University Press, 1992.

WEST, Robin L., From choice to reproductive justice: de-constitutionalizing abortion rights. Yale Law Journal, Vol. 118, No. 7, November 17, 2009, p. 1394-1431. Disponível em: $<$ http://ssrn.com/ abstract=1508035>. Acesso em 22 jul. 2014. 